\title{
Biaya Pengurangan (Marginal Abatement Cost) Emisi Gas Rumah Kaca(GRK) Sektor PErtanian di Kabupaten Grobogan dan Tanjung Jabung Timur
}

\author{
Miranti Ariani ${ }^{1}$, P. Setyanto ${ }^{1}$, M. Ardiansyah ${ }^{2}$ \\ ${ }^{1}$ Balai Penelitian Lingkungan Pertanian Pati; email: mirantiariani@yahoo.com \\ ${ }^{2}$ Climate Change Risk and Opportunity Management in South East Asia, Institut Pertanian Bogor
}

\begin{abstract}
ABSTRAK
Komitmen Pemerintah Indonesia untuk penurunan emisi GRK sebesar 26\% sampai 2020, melibatkan keikutsertaan daerah secara aktif. Penelitian ini bertujuan menganalisis opsi-opsi mitigasi pada pengelolaan lahan sawah yang mungkin dilakukan dengan menggunakan pendekatan Marginal Abatement Cost atau biaya pengurangan emisi yang berprinsip pada pemilihan aksi mitigasi dengan biaya rendah dan potensi penurunan yang besar. Lokasi penelitian dipilih secara purposive yaitu di Kabupaten Grobogan Propinsi Jawa Tengah dan Kabupaten Tanjung Jabung Timur Propinsi Jambi pada tahun 2013 untuk analisis tahun 2011. Hasil penelitian menunjukkan teknologi mitigasi yang berpotensi besar menurunkan emisi GRK dengan biaya rendah di Kabupaten Grobogan adalah penerapan teknik budidaya padi dengan penerapan Pengelolaan Tanaman Terpadu (PTT) dan penggantian varietas padi dengan varietas padi yang rendah emisi GRK. Sementara di Kabupaten Tanjung Jabung Timur, teknologi ameliorasi dengan kompos, pupuk kandang dan penerapan teknologi tanpa olah tanah+tanam benih langsung merupakan teknologi mitigasi yang memiliki potensi besar menurunkan emisi dengan biaya yang rendah.
\end{abstract}

Kata kunci: pertanian, gas rumah kaca, biaya pengurangan emisi, mitigasi

\begin{abstract}
The Indonesian government's commitment to decrease GHG emissions by $26 \%$ until 2020, actively involve local government's participation. This study aims to analyze mitigation options inpaddy fields management that may be performed by using the approach of Marginal Abatement Cost with the principle of selecting mitigation actions with low cost and high potential emission decrease. Locations were selected purposively in Grobogan Central Java Province and East Tanjung Jabung Jambi in 2013 for 2011 data analysis. The results show mitigation activity such as low methane rice varieties and Integrated Crop Management could be applied at Grobogan with low cost, while using amelioration such as compost or manure and non tillage+direct seeded could be applied at East Tanjung Jabung with low cost as well.
\end{abstract}

Keywords: agriculture, greenhouse gas, marginal abatement cost, mitigation

Cara sitasi: Arianti, M., Setyanto, P., Ardiansyah, M. (2016). Biaya Pengurangan (Marginal Abatement Cost) Emisi Gas Rumah Kaca(GRK) Sektor PErtanian di Kabupaten Grobogan dan Tanjung Jabung Timur. Jurnal Ilmu Lingkungan. 14(1),39-49, doi:10.14710/jil.14.1.39-49

\section{PENDAHULUAN}

Sektor pertanian secara langsung berkaitan dengan isu perubahan iklim dalam aspek lingkungan, ekonomi dan sosial dan dianggap sebagai sektor yang paling rentan terhadap perubahan iklim itu sendiri. Di satu sisi, kegiatan adaptasi adalah kunci keberhasilan sektor pertanian dalam menghadapi perubahan iklim dan mempertahankan keamanan pangan, baik pada skala global, nasional maupun daerah. Di sisi lain, pertanian menyumbangkan emisi gas rumah kaca (GRK) sekitar 14\% pada skala global dan 7\% pada skala nasional (Second Natcom, 2010). Sebagai sektor kunci dalam pemenuhan kebutuhan pangan, emisi sektor pertanian diperkirakan akan terus meningkat sampai tahun 2030 seiring dengan peningkatan kebutuhan pangan. Untuk mengatasi hal ini. Pemerintah Indonesia telah berkomitmen untuk menurunkan emisi GRK sebesar $26 \%$ pada tahun 2020. Target untuk sektor pertanian adalah sebesar $8 \mathrm{Gg} \mathrm{CO}_{2} \mathrm{e}$.

Teknologi mitigasi GRK untuk pertanian telah banyak dihasilkan, baik di tingkat global (DeAngelo et al, 2006; Verge et al, 2007) maupun nasional (Setyanto et al, 2005; Setyanto et al, 2011). Teknologi mitigasi tersebut antara lain adalah penerapan system pengairan secara berselang-seling antara kondisi basah dan kering, penggunaan varietas padi dengan emisi 
yang rendah serta penggunaan bahan-bahan pembenah tanah. Selain itu, banyak estimasi yang mengindikasikan bahwa beberapa opsi mitigasi dari pertanian relatif lebih rendah biaya dan menghasilkan keuntungan yang signifikan dalam peningkatan produksi dibandingkan dengan sektor yang lain (Smith et al 2006, 2008; Beach et al, 2008; MacLeod et al, 2010). Penggunaan pendekatan biaya pengurangan atau marginal abatement cost (MAC) ini diperlukan untuk membuat pilihan terhadap opsi mitigasi yang sesuai. Pendekatan MAC adalah besarnya tambahan biaya yang diperlukan untuk menurunkan emisi GRK sebesar $1 \mathrm{t} \mathrm{CO}_{2} \mathrm{e}$ hingga kurun waktu tertentu. Secara umum, analisis MAC digunakan untuk menilai potensi ekonomi sektor pertanian dalam pengurangan emisi GRK (MacLeod et al, 2010; Moran et al, 2011). Analisis MAC memungkinkan untuk melakukan evaluasi terhadap strategi untuk mengurangi GRK terhadap beberapa skenario referensi yang meliputi biaya maupun manfaat yang diterima. Konsep ini telah banyak dikembangkan selama 20 tahun terakhir (Beach et al, 2008). Beberapa penelitian telah dilakukan untuk mengembangkan konsep MAC dalam konteks perubahan iklim, McKinsey \& Company (2008, 2009) dan United States Environmental Protection Agency (USEPA) melakukan analisis ini untuk pengurangan emisi semua sektor di USA, Asian Development Bank melalui Asia Leastcost Greenhouse Gas Abatement Strategy (ADB, 1998) dan Dewan Nasional Perubahan Iklim (DNPI, 2009) membuat analisis ini untuk semua sektor di Indonesia. Untuk sektor pertanian, pendekatan ini mulai digunakan sekitar tahun 2000 dengan menggunakan pendapat secara kualitatif (Weiske 2005,2006) dan beberapa penelitian empiris telah dilakukan di USA dan Uni Eropa (Beach et al, 2008; Macleod et al, 2010; Vermont dan DeCara, 2010; De Cara et al, 2011).

Secara umum, analisis MAC digunakan untuk menilai potensi ekonomi sektor pertanian dalam pengurangan emisi GRK (MacLeod et al, 2010; Moran et al, 2011). Analisis ini menyediakan opsi mitigasi GRK, di mana opsi tersebut merupakan tambahan untuk kegiatan mitigasi yang diharapkan akan diberikan pada skenario'business as usual' (Moran et al, 2011). MAC menghasilkan kuantifikasi besarnya emisi GRK yang dapat dikurangi dengan berbagai opsi mitigasi dan mengurutkannya sesuai dengan biaya marjinal yang dibutuhkan. Analisis MAC ini bersifat tidak tetap dan akan berubah dari waktu ke waktu seiring teknologi baru menjadi lebih banyak tersedia dengan biaya yang lebih rendah atau berkembangnya kondisi agronomi dan sosial-ekonomi.
Sebelum melakukan analisis MAC yang harus dilakukan terlebih dahulu adalah mengetahui emisi actual di suatu wilayah, kemudian memperkirakan kecenderungannya sampai kurun waktu tertentu.

Penelitian ini dilakukan untuk menganalisis opsi-opsi mitigasi pada pengelolaan lahan sawah yang mungkin dilakukan menggunakan pendekatan MAC dengan beberapa langkah, yaitu: penentuan teknologi mitigasi, potensi penurunan emisi serta tambahan biaya yang diperlukan pada berbagai teknologi mitigasi dengan menggunakan data biaya yang spesifik lokasi, menyusun kurva MAC sehingga diharapkan dapat membantu daerah dalam memilih opsi mitigasi dengan biaya rendah dan potensi penurunan emisi yang besar.

\section{METODE PENELITIAN}

\subsection{Lokasi, Waktu Penelitian, dan Data}

Penelitian ini dilaksanakan di 2 Kabupaten yaitu Kabupaten Grobogan Propinsi Jawa Tengah dan Kabupaten Tanjung Jabung Timur Propinsi Jambi. Propinsi Jawa Tengah dan Propinsi Jambi adalah 2 propinsi yang sampai dengan bulan Oktober 2011 telah menerbitkan Peraturan Gubernur mengenai RAD GRK (Bappenas, 2012). Sedangkan Kabupeten Grobogan dan Tanjung Jabung Timur masingmasing adalah kabupaten dengan sumber mata pencaharian utama penduduk adalah di bidang pertanian. Sektor pertanian di Kabupaten Grobogan tahun 2011 berkontribusi sebesar $43 \%$ terhadap total PDRB, sedangkan di Kabupaten Tanjung Jabung Timur berkontribusi sebesar 59\% dengan pertumbuhan sebesar $1,2 \%$. Data yang dikumpulkan meliputi data luas panen sawah, populasi ternak, penggunaan pupuk serta analisa usahatani spesifik lokasi tahun 2011.

\subsection{Metode Penyusunan Kurva Biaya Pengurangan}

1. Menyusun proyeksi BAU baseline sampai periode waktu tertentu sesuai yang di skenariokan

2. Pengumpulan dan penyaringan terhadap teknologi-teknologi mitigasi GRK dari lahan sawah dari beberapa hasil penelitian yang telah ada.

3. Menghitung abatement cost $\left(\mathrm{Rp} / \mathrm{tCO}_{2} \mathrm{e}\right)$ untuk masing-masing aksi mitigasi dalam poin 2

a. Dengan menggunakan data biaya dan penerimaan riil usahatani sebagai BAU baseline biaya dan penerimaan 
b. Menghitung prakiraan biaya dan penerimaan usahatani untuk masingmasing aksi mitigasi

c. Biaya yang diperhitungkan dalam penelitian hanya biaya tenaga kerja, biaya input produksi dan sewa lahan, sementara biaya - biaya sosial, pajak dan bahan bakar selama proses usahatani belum diperhitungkan

d. Menentukan tingkat diskonto (discount rate) yaitu sebesar $8 \%$ yang merupakan suku bunga nyata untuk negara-negara berkembang dan banyak digunakan oleh World Bank dalam analisis ekonominya (Sathaye, 1995)

e. Menghitung abatement cost dengan pendekatan Net Present Value (NPV) seperti yang digunakan dalam International Energy Agency (IEA, 2009) dan Food \& Agricultural Organization (FAO, 2010)

$$
\mathrm{NPV}=\sum_{t=1}^{T} \frac{C t}{(1+r)^{t}}-C 0
$$

$\mathrm{Ct}=$ cash flow atau aliran kas yang diterima tiap tahun

$\mathrm{C} 0=$ Investasi awal

$\mathrm{R}=$ tingkat diskonto (discount rate)

$\mathrm{T}=$ durasi proyek

$$
\mathrm{MAC}=\frac{N P V \text { mitigasi }-N P V B A U}{\text { Emisi GRK BAU - Emisi GRK mitigasi }}
$$

4. Menghitung abatement potential (AP) yaitu besarnya GRK yang dapat dikurangi per tahunnya dengan persamaan :

$\mathrm{AP}=\mathrm{AR} \times$ luasan lahan yang berpotensi dilakukan aksi mitigasi

AP = besarnya GRK yang dapat dikurangi tiap tahunnya

$\mathrm{AR}$ = abatement rate yaitu besarnya GRK yang dapat dikurangi per hektar lahan

Perhitungan ini berdasarkan pada asumsi bahwa sekali aksi mitigasi dilakukan, maka akan berlangsung sampai kurun waktu yang telah ditentukan dalam skenario.

5. Perhitungan abatement rate juga dilakukan untuk interaksi antara 2 teknologi mitigasi.

6. Menentukan tingkat kemungkinan adopsi dari masing-masing aksi mitigasi pada 4 kategori berdasarkan pada Moran et al, (2010) dan Mac Leod et al, (2010) sebagi berikut :
a. Maximum technical
b. High feasibility
c. Central feasibility
d. Low feasibility

(b) Kabupaten Tanjung Jabung Timur

7. Menyusun kurva biaya pengurangan (MAC Curve) emisi GRK.

8. Menghitung potensi penurunan emisi GRK pada akhir periode skenario terhadap proyeksi BAU baseline.

\section{HASIL DAN PEMBAHASAN}

\subsection{Karakteristik Wilayah Penelitian}

(a) Kabupaten Grobogan

Kabupaten Grobogan secara geografis terletak di provinsi Jawa Tengah dengan posisi geografis $110^{\circ} 15^{\prime}$ BT 11125 BT dan 7으 LS - 7은 LS dengan landform berupa daerah pegunungan kapur, perbukitan dan dataran di bagian tengahnya.

Berdasarkan letak geografis dan reliefnya, Kabupaten Grobogan merupakan Kabupaten yangtiang penyangga perekonomiannya berada pada sektor pertanian dan merupakan daerah yang cenderung sulit mendapatkan air bersih. Hasil laporan statistik tahunan (BPS, 2010) menyebutkan bahwa luas wilayah Kabupaten Grobogan seluruhnya adalah 197.586 ha yang terdiri dari :

○ Tanah Sawah : 64.790 ha dimana 20.278 ha adalah sawah tadah hujan

- Perkebunan rakyat : 5.190 ha

- Hutan nasional : 68.633 ha

- Penggunaan lainnya

Kabupaten Tanjung Jabung Timur secara geografis terletak pada $0^{\circ} 53^{\prime}-1^{\circ} 41^{\prime}$ LS dan $103^{\circ} 23$ - $104^{\circ} 31$ BT dengan luas $5.445 \mathrm{~km}^{2}$. Kabupaten Tanjung Jabung Timur mempunyai ketinggian kurang lebih 0 - 100 m dari permukaan laut. Topografi daerah pada umumnya dataran rendah terdiri dari rawa/gambut dengan permukaan tanah banyak dialiri pasang surut air laut. Kabupaten Tanjung Jabung Timur yang secara topografi kawasan mempunyai kelerengan antara $0-3 \%$ (datar). Kawasan ini dapat dikembangkan sebagai kawasan pertanian dengan syarat adanya input drainase, yang berfungsi juga sebagai saluran irigasi karena adanya pengaruh arus pasang. Menurut laporan statistik tahunan (BPS, 2011) luas keseluruhan kabupaten ini adalah sekitar 270.000 ha yang terdiri dari :

- Tanah sawah : 29.594 ha, dimana 26.160 ha merupakan sawah pasang surut

- Perkebunan rakyat : 101.000 ha

- Perkebunan besar : 48.514 ha

- Penggunaan lainnya 


\subsection{Pengumpulan Data}

Pengumpulan data aktivitas adalah bagian terpenting dalam melakukan kegiatan inventarisasi GRK. Data aktivitas sektor pertanian adalah satuan kegiatan manusia di bidang pertanian yang diperkirakan menimbulkan emisi GRK, seperti: jumlah dan jenis ternak, pengelolaan kotoran ternak, luasan tanam padi sawah, jenis irigasi, pertanaman di lahan kering, penggunaan pupuk, dan lain sebagainya. Data seperti ini sebagian sudah tersedia dan tercatat di dinas terkait yaitu Dinas Pertanian maupun Badan Pusat Statistik. Akan tetapi, beberapa data seperti cara pengelolaan kotoran ternak, jumlah pupuk urea atau $\mathrm{N}$ dalam setahun baik pada lahan sawah maupun lahan kering, dan luas penggunaan varietas padi tertentu, kebanyakan belum tercatat dengan baik.

Pada kasus jumlah pupuk N, umumnya data yang tercatat adalah realisasi pupuk musiman dari distributor terutama untuk tanaman pangan, sementara untuk perkebunan tidak tersedia. Untuk mendapatkan jumlah pupuk $\mathrm{N}$ dalam setahun, diperoleh dengan mengalikan luas tanam masing-masing pertanaman dengan dosis rekomendasi. Data mengenai bentuk pengelolaan kotoran ternak dan luas varietas padi yang digunakan juga tidak tercatat, oleh karena itu dilakukan survei langsung ke lapang dan wawancara dengan petugas lapang ataupun petani.

Luas panen lahan sawah dihitung dengan mengalikan luas tanam dengan masa tanamnya. Masing-masing luas tanam sawah, sudah terbagi ke dalam beberapa jenis pengairan (irigasi teknis, setengah teknis, sederhana, tadah hujan maupun pasang surut (khusus di Tanjung Jabung Timur). Luas panen sawah Kabupaten Grobogan hampir 3 kali lipat Kabupaten Tanjung Jabung Timur (Tabel 2.9). Lebih dari $80 \%$ luas panen Tanjung Jabung Timur adalah di lahan pasang surut dengan jenis tanah gambut. Selain luas panen sawah dan jenis pengairan, data aktivitas yang dikumpulkan juga yaitu penggunaan varietas padi. Di Kabupaten Grobogan, tahun 2006 varietas padi yang dominan dibudidayakan yaitu IR64 (57\%) dan ciherang (41\%) dengan 2\% adalah varietas lain. Mulai tahun 2010, ciherang menjadi yang paling dominan yaitu sebesar 87\%, sedangkan IR 64 hanya $7 \%$ dan varietas lain 6\%. Di Tanjung Jabung Timur tahun 2006, varietas yang dominan adalah IR 42 (hampir 80\%) dan 20\% adalah varietas lain. Mulai tahun 2010, varietas Batanghari menjadi yang paling dominan,

Data aktivitas dan faktor emisi yang digunakan dalam perhitungan dapat dilihat pada Tabel 1, 2 dan 3.

Tabel 1.Data aktivitas sub sektor pertanian

\begin{tabular}{|c|c|c|c|c|c|c|c|c|}
\hline \multirow{2}{*}{ Tahun } & \multicolumn{2}{|c|}{ Luas panen sawah (ha) } & \multicolumn{2}{|c|}{$\begin{array}{l}\text { Pupuk N di lahan } \\
\text { sawah (t N/th) }\end{array}$} & \multicolumn{2}{|c|}{$\begin{array}{l}\text { Pupuk N di lahan kering } \\
\text { (t N/th) }\end{array}$} & \multicolumn{2}{|c|}{ Pupuk Urea t/th } \\
\hline & Grobogan & Tanjabtim & Grobogan & Tanjabtim & Grobogan & Tanjabtim & Grobogan & Tanjabtim \\
\hline 2006 & 100.707 & 32.775 & 11.653 & 3.675 & 31.746 & 24.514 & 80.102 & 55.322 \\
\hline 2007 & 99.933 & 34.043 & 11.895 & 3.740 & 34.980 & 28.508 & 77.842 & 62.354 \\
\hline 2010 & 107.915 & 29.848 & 14.640 & 3.566 & 27.607 & 36.896 & 74.233 & 79.215 \\
\hline 2011 & 108.915 & 29.594 & 16.627 & 3.419 & 30.799 & 42.584 & 78.408 & 91.017 \\
\hline
\end{tabular}

Tabel Error! No text of specified style in document..Data aktivitas sub sektor peternakan Kabupaten Grobogan

\begin{tabular}{|c|c|c|c|c|c|c|}
\hline \multirow{2}{*}{ Jenis Ternak } & \multicolumn{6}{|c|}{ Populasi Ternak (Ekor) } \\
\hline & 2006 & 2007 & 2008 & 2009 & 2010 & 2011 \\
\hline Sapi perah & 388 & 332 & 335 & 335 & 336 & 426 \\
\hline Sapi potong & 105.154 & 105.549 & 137.322 & 137.843 & 160.838 & 212.409 \\
\hline Kerbau & 1.937 & 1.206 & 2.476 & 2.545 & 2.536 & 2.581 \\
\hline Kuda & 722 & 589 & 488 & 494 & 489 & 484 \\
\hline Kambing & 99.969 & 111.928 & 105.252 & 104.703 & 115.394 & 111.839 \\
\hline Babi & & & 215 & 215 & 125 & 139 \\
\hline Domba & 15.625 & 16.634 & 15.422 & 14.936 & 18.938 & 29.528 \\
\hline Ayam Buras & 940.531 & 1.420 .824 & 1.204 .524 & 1.146 .639 & 1.115 .794 & 985.995 \\
\hline
\end{tabular}


Arianti, M., Setyanto, P., Ardiansyah, M. (2016). Biaya Pengurangan (Marginal Abatement Cost) Emisi Gas Rumah Kaca(GRK) Sektor PErtanian di Kabupaten Grobogan dan Tanjung Jabung Timur. Jurnal IImu Lingkungan. 14(1),39-49, doi:10.14710/jil.14.1.39-49

\begin{tabular}{lrrrrrr} 
Ayam ras (petelur) & 36.450 & 42.000 & 42.000 & 52.800 & 52.800 & 40.466 \\
$\begin{array}{l}\text { Ayam Ras } \\
\text { (pedaging) }\end{array}$ & 1.064 .800 & 300.000 & 264.500 & 278.000 & 297.097 & 200.965 \\
Itik & 94.872 & 102.102 & 64.617 & 103.041 & 102.945 & 83.412 \\
Itik & 84.489 & 92.697 & 64.617 & 92.650 & 92.650 & 83.412 \\
Itik Manila & 10.383 & 9.405 & & 10.391 & 10.295 & 5.462 \\
Angsa & 2.312 & 5.317 & 4.785 & 5.331 & 5.775 \\
Burung Puyuh & 69.608 & 48.377 & 57.173 & 55.483 & 59.233 & 47.596 \\
Kelinci & 10.869 & 12.901 & 12.587 & 15.170 & 15.236 & 12.776 \\
\hline
\end{tabular}

Tabel 3.Data aktivitas sub sektor peternakan Kabupaten Tanjung Jabung Timur

\begin{tabular}{|c|c|c|c|c|c|c|}
\hline \multirow{2}{*}{ Jenis Ternak } & \multicolumn{6}{|c|}{ Populasi Ternak (Ekor) } \\
\hline & 2006 & 2007 & 2008 & 2009 & 2010 & 2011 \\
\hline Sapi & 8.746 & 9.742 & 10.225 & 11.458 & 13.327 & 13.627 \\
\hline Kerbau & 449 & 451 & 458 & 530 & 178 & 197 \\
\hline Kambing & 13.497 & 14.444 & 15.142 & 24.080 & 24.156 & 32.378 \\
\hline $\begin{array}{l}\text { Domba } \\
\text { Ayam }\end{array}$ & 118 & 99 & 123 & 118 & 104 & 115 \\
\hline kampung/buras & 237.136 & 237.942 & 239.798 & 387.270 & 416.146 & 621.988 \\
\hline Ayam broiler & 56.980 & 58.360 & 22.480 & 33.050 & 127.931 & 112.161 \\
\hline Itik & 27.737 & 30.186 & 31.460 & 28.303 & 29.744 & 32.860 \\
\hline
\end{tabular}

Berdasarkan data aktivitas tersebut, maka besaran emisi dari sektor pertanian di masing-masing daerah dapat diketahui. Penyusunan rencana aksi mitigasi, selain memerlukan informasi status emisi, diperlukan juga baseline emisi hingga beberapa tahun ke depan yang telah ditentukan. Hal ini penting untuk menentukan berapa target emisi yang akan diturunkan. Proyeksi ke depan ini lazim disebut sebagai BAU (Business as Usual) baseline, yaitu prakiraan tingkat emisi yang dihitung berdasarkan pada asumsi jika tidak ada kegiatan mitigasi yang dilakukan menunjukkan kecenderungan kenaikan secara linier dari tahun ke tahun.

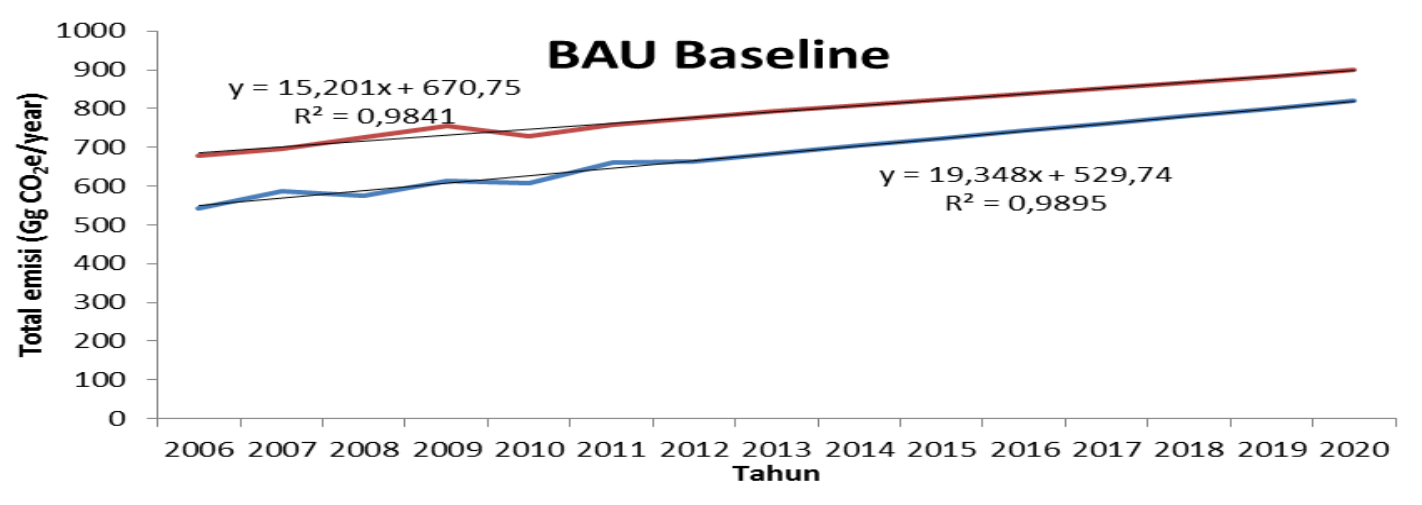

Gambar 1. BAU Baseline emisi GRK Kabupaten Grobogan dan Kabupaten Tanjung Jabung Timur

Total emisi GRK Kabupaten Grobogan dengan metode IPCC 2006 adalah sekitar 678-758 $\mathrm{Gg} \mathrm{CO}_{2}$ e dan diperkirakan akan terus meningkat mencapai angka $898 \mathrm{Gg} \mathrm{CO}_{2} \mathrm{e}$ di tahun 2020 jika tidak ada aksi mitigasi, sedangkan di Kabupaten Tanjung Jabung
Timur sekitar 543-659 $\mathrm{Gg} \mathrm{CO}_{2}$ e dan mencapai angka $820 \mathrm{Gg} \mathrm{CO}_{2}$ e tahun 2020.

Penyaringan terhadap aksi mitigasi yang berpotensi diterapkan di Kabupaten Grobogan dan Tanjung Jabung Timur dilakukan melalui studi literature dari hasilhasil penelitian yang telah dilakukan. Dari 
hasil studi dipilih 7 teknologi mitigasi dari 5 sumber publikasi [ADB,1998; Lolingtan 19971999; Setyanto et al,2005; Setyanto et al,
2011; Balingtan 2008-2012 dan Susilawati et $a l, 2010]$ seperti dalam Tabel 4 berikut ini,

Tabel 4.Teknologi mitigasi GRK dari beberapa sumber publikasi

\begin{tabular}{|c|c|c|}
\hline Teknologi mitigasi & Potensi pengurangan & Hasil padi \\
\hline Tanam benih langsunga & $37 \mathrm{~kg} \mathrm{CH}_{4} / \mathrm{ha}$ & Naik 4,5\% \\
\hline Penggantian urea prill dengan urea tableta & $18,1 \mathrm{~kg} \mathrm{CH}_{4} / \mathrm{ha}$ & Naik $20,5 \%$ \\
\hline Penggunaan varietas rendah emisi ${ }^{\mathrm{b}}$ & $57 \%$ & Naik 15\% \\
\hline PTT (pengairan berselang/intermittent)c & $46 \%$ & Naik 5\% \\
\hline Ameliorasi dengan kompos ${ }^{d}$ & $19 \%$ & Naik 23\% \\
\hline Ameliorasi dengan pupuk kandang $\mathrm{d}$ & $13 \%$ & Naik 25\% \\
\hline Tanpa Olah Tanah+Tanam benih langsunge & $70 \%$ & Naik 3\% \\
\hline $\begin{array}{l}\text { aADB (1998) } \\
\text { bSetyanto et,al (2005) } \\
\text { cSetyanto et,al ( 2011) } \\
\text { dBalingtan (2008-2012), Susilawati et al (2010) } \\
\text { eLolingtan (1997-1999) }\end{array}$ & & \\
\hline
\end{tabular}

Setiap aksi mitigasi yang telah dipilih terdapat didalamnya besaran potensi pengurangan emisi serta pengaruhnya terhadap hasil padi (Tabel 4). Perhitungan potensi pengurangan emisi $\left(\mathrm{tCO}_{2} \mathrm{e} / \mathrm{ha}\right)$ didasarkan pada emisi $\mathrm{CH}_{4}$ rata-rata dari lahan sawah di Indonesia yaitu $160,9 \quad \mathrm{~kg} \quad \mathrm{CH}_{4} / \mathrm{ha} /$ musim. Sementara, biaya tambahan untuk melakukan tindakan pengurangan emisi dihitung dengan pendekatan NPV yaitu nilai ekonomi yang biasa digunakan dalam analisis prakiraan keuntungan atau investasi dalam periode tertentu (Tabel 5). NPV ini menggambarkan perbedaan nilai sekarang dari aliran penerimaan di masa mendatang dari sebuah investasi berdasarkan tingkat diskon tertentu. Analisa NPV biasa digunakan untuk menilai kelayakan sebuah proyek yang akan dijalankan.

Tabel 5. Potensi pengurangan emisi (Abatement rate) dan biaya tambahan untuk pengurangan emisi (abatement cost)

\begin{tabular}{lcrc}
\hline Teknologi mitigasi & \multicolumn{2}{c}{$\begin{array}{c}\text { Abatement rate } \\
\left(\mathrm{tCO}_{2} \mathrm{e} / \mathrm{ha}\right)\end{array}$} & \multicolumn{2}{c}{ Abatement cost $\left(\mathrm{Rp} / \mathrm{tCO} \mathrm{C}_{2} \mathrm{e}\right)$} \\
\cline { 3 - 4 } & & 657 & 504 \\
Tanam benih langsung & 1,6 & 3.582 & \\
Penggantian urea prill dengan urea tablet & 0,8 & 106 & \\
Penggunaan varietas rendah emisi & 3,9 & 124 & 163 \\
PTT (pengairan berselang/intermiten) & 3,1 & & 456 \\
Ameliorasi dengan kompos & 1,3 & & 608 \\
Ameliorasi dengan pupuk kandang & 1,7 & & \\
Tanpa olah tanah+tanam benih langsung & 2,6 & & \\
\hline
\end{tabular}

\subsection{Abatement Potential}

Abatement potential atau potensi pengurangan dihitung berdasarkan asumsi sebagai berikut:

1. Kabupaten Grobogan :

- Teknologi tanam benih langsung diterapkan pada lahan sawah di daerah tadah hujan yang hanya 1 kali tanam dalam setahun karena minimnya curah hujan yaitu seluas 20.278 ha. Pada perhitungan existing emisi, faktor skala rejim air untuk daerah tadah hujan yaitu sebesar 0,49 sudah dimasukkan.

- Teknologi penggunaan variets rendah emisi, bisa diterapkan di daerah irigasi $1 / 2$ teknis, sederhana dan desa. Pada perhitungan existing emisi di lahan tersebut, faktor skala rejim pengairan berselang sudah dimasukkan sesuai kondisi di lapang.
- Teknologi pengairan berselang bisa diterapkan pada daerah irigasi teknis, dimana di daerah ini, air selalu tersedia sehingga lahan sawah selalu dalam kondisi tergenang karena petani masih memaksimalkan ketersediaan air untuk pengairan. Pengenalan dan penerapan teknologi ini selain akan lebih menghemat air, hasil padi juga akan meningkat.

- Teknologi penggantian urea prill dengan urea tablet juga sesuai untuk diterapkan di lahan sawah yang selalu tergenang, dimana potensi pembentukan gas $\mathrm{CH}_{4}$ besar. Meskipun teknologi ini mempunyai potensi penurunan emisi yang cukup besar dan meningkatkan hasil padi, akan tetapi karena harga urea tablet lebih mahal dibandingkan urea prill, kemungkinan 
tingkat adopsi oleh petani adalah rendah. Maka dari itu proporsi teknologi ini untuk diterapkan juga pada areal yang sempit yaitu sekitar $20 \%$ dari luasan daerah irigasi. Hal ini diasumsikan dengan adanya subsidi atau bantuan dari pemerintah.

2. Kabupaten Tanjung Jabung Timur :

- Teknologi tanam benih langsung bisa diterapkan di daerah tadah hujan, yaitu pada areal lahan sawah seluas 1.542 ha dengan pertimbangan di daerah ini ketersediaan air terbatas.

- Teknologi kombinasi tanpa olah tanah dan tanam benih langsung, bisa diterapkan terutama di daerah pasang surut. Lahan sawah di kabupaten ini 80\% dari total berada di daerah pasang surut. Lahan pasang surut sendiri terdiri dari $70 \%$ bergambut dan sisanya tidak bergambut. Luas lahan pasang surut tidak bergambut yaitu sekitar 8.873 ha dan 20.703 ha lainnya merupakan daerah pasang surut bergambut. Pada lahan pasang surut bergambut, selain diterapkan teknologi tanpa olah tanah dan tanam benih langsung, juga bisa diterapkan teknologi ameliorasi dengan kompos maupun pupuk kandang.

Tabel 6. Abatement potensial dan kemungkinan adopsi teknologi mitigasi

\begin{tabular}{|c|c|c|c|}
\hline \multirow[t]{2}{*}{ Teknologi Mitigasi } & \multirow[t]{2}{*}{ Kemungkinan adopsia } & \multicolumn{2}{|c|}{$\begin{array}{c}\text { Abatament Potential } \\
\left(\mathrm{tCO}_{2} \mathrm{e} / \text { tahun }\right)\end{array}$} \\
\hline & & Grobogan & Tanjabtim \\
\hline Tanam benih langsung & Low feasible & 31.512 & 2.396 \\
\hline Penggantian urea prill dengan urea tablet & Central feasible & 5533 & \\
\hline Penggunaan varietas rendah emisi & High feasible & 90.776 & \\
\hline PTT (pengairan berselang/intermiten) & High feasible & 90.534 & \\
\hline Ameliorasi dengan kompos & High feasible & & 5.317 \\
\hline Ameliorasi dengan pupuk kandang & High feasible & & 13.987 \\
\hline Tanpa olah tanah+tanam benih langsung & High feasible & & 44.618 \\
\hline
\end{tabular}
aMoran et al (2010), MacLeod etal (2010)

Tabel 7. Potensi penurunan hingga tahun 2020 terhadap proyeksi emisi BAU baseline

\begin{tabular}{|c|c|c|c|}
\hline \multicolumn{2}{|c|}{ Emisi tahun $2020 \mathrm{BAU}\left(\mathrm{tCO}_{2} \mathrm{e}\right)$} & \multicolumn{2}{|c|}{ Emisi tahun 2020 Mitigasi $\left(\mathrm{tCO}_{2} \mathrm{e}\right)$} \\
\hline Grobogan & Tanjabtim & Grobogan & Tanjabtim \\
\hline 897.967 & 820.740 & 679.540 & 753.682 \\
\hline
\end{tabular}

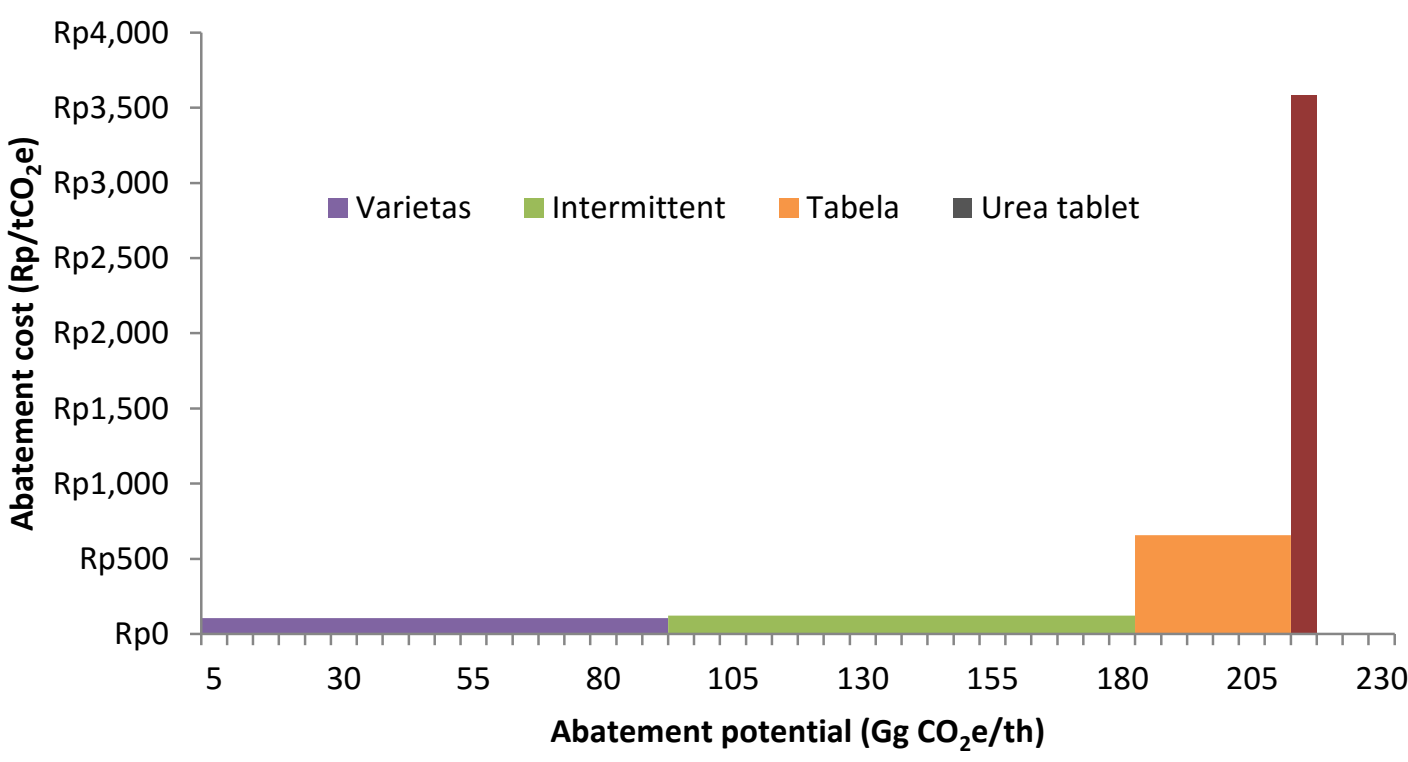

Gambar 2. Kurva biaya pengurangan emisi GRK Kabupaten Grobogan 


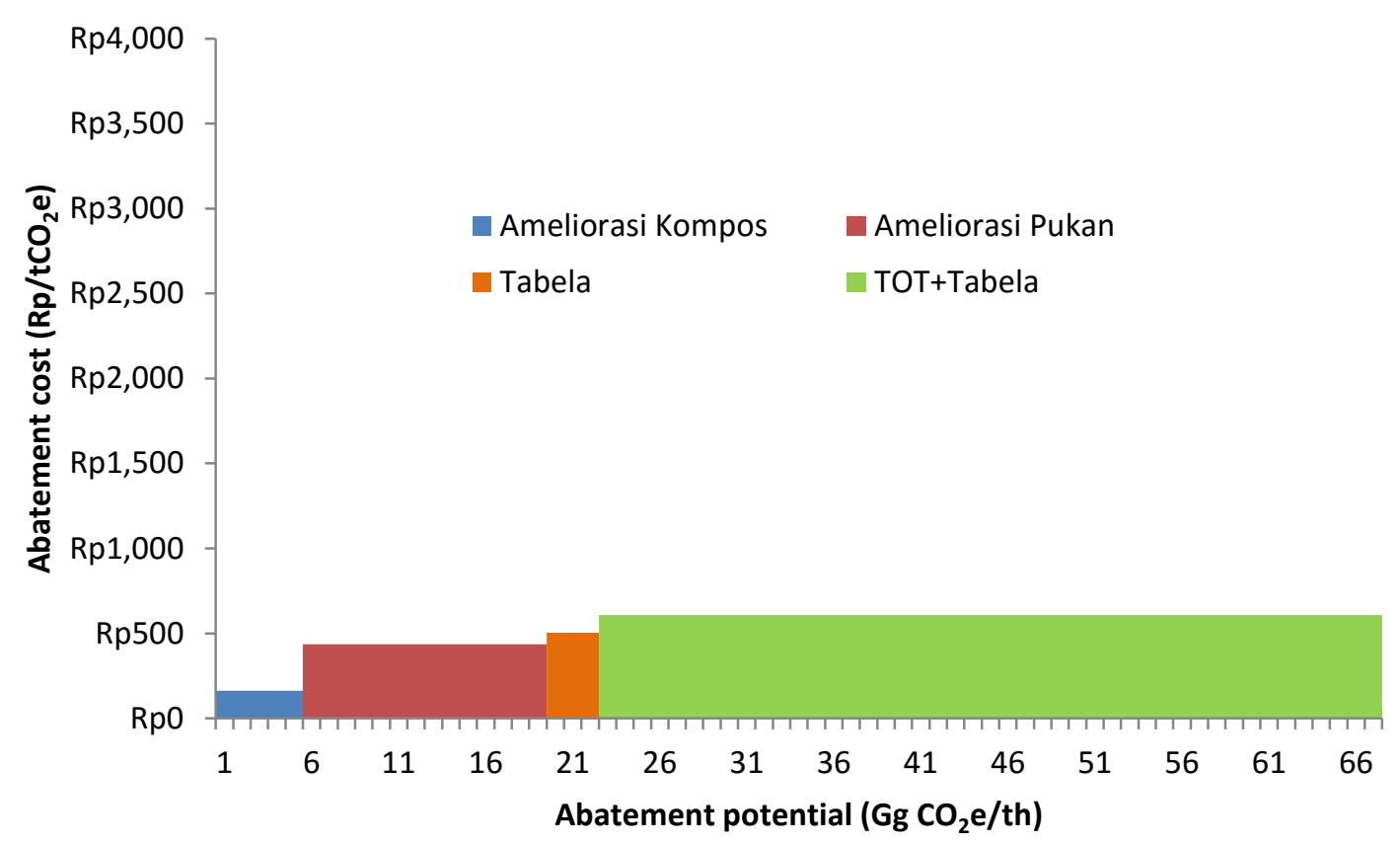

Gambar 3. Kurva biaya pengurangan emisi GRK Kabupaten Tanjung Jabung Timur

Penerapan PTT merupakan kebijakan yang telah diterapkan pemerintah melalui keputusan menteri pertanian, dan penggunaan varietas rendah emisi dimungkinkan untuk diterapkan dengan adanya peraturan yang sejenis. Teknologi PTT adalah suatu pendekatan inovatif dalam upaya meningkatkan produktivitas dan efisiensi usahatani. Peningkatan produktivitas dilakukan melalui pemakaian benih varietas unggul bermutu produktivitas tinggi termasuk benih padi hibrida dan jagung hibrida, sistem jarak tanam jajar legowo, pemupukan berimbang dan pemakaian pupuk organik serta pupuk biohayati, pengelolaan pengairan dan perbaikan budidaya disertai pengawalan, pendampingan, pemantauan dan koordinasi. Strategi ini terutama dilaksanakan di wilayah dimana perluasan areal sudah sulit dilakukan, sehingga dengan penerapan teknologi spesifik lokasi diharapkan masih dapat ditingkatkan produktivitasnya. Berdasarkan hasil penelitian Setyanto et al (2011), dihitung dari komponen pengelolaan pengairannya, teknologi ini secara signifikan mampu menurunkan emisi GRK dari lahan padi sawah.

Varietas padi rendah emisi adalah varietas padi yang teridentifikasi melalui berbagai hasil penelitian menghasilkan emisi $\mathrm{CH}_{4}$ lebih rendah dibandingkan dengan varietas padi yang lain. Metanaadalah GRK yang dihasilkan melalui dekomposisi bahan organik secara anaerobik (Cao et al, 1995; Levy et al, 2007). Kemampuan varietas mengemisi gas metan bergantung kepada rongga aerenkhima, jumlah anakan, biomassa, sistem perakaran, dan aktivitas metabolisme (Aulakh, 2001).Proses pembentukan metan merupakan akibat dari dekomposisi bahan organik pada kondisi anaerob. Tanaman padi memegang peran penting dalam emisi gas $\mathrm{CH}_{4}$ dari lahan sawah. Kurang lebih $90 \% \mathrm{CH}_{4}$ yang dilepas dari lahan sawah ke atmosfir diemisikan melalui tanaman dan sisanya melalui gelembung air (ebullition). Ruang udara pada pembuluh aerenkima yang terdapat pada daun, batang dan akar yang berkembang dengan baik menyebabkan pertukaran gas pada tanah tergenang (anaerob) berlangsung cepat (Aulakh, 2002). Pembuluh aerenkima bertindak sebagai cerobong (chimney) untuk lepasnya $\mathrm{CH}_{4}$ ke atmosfir. Keragaman emisi gas metan dari lahan sawah ditentukan oleh perbedaan sifat fisiologi dan morfologi varietas padi (Las, 2007; Setyanto et al, 2010).

Penggantian urea pril dengan urea tablet mempunyai tingkat penurunan emisi yang cukup besar, akan tetapi teknologi mitigasi ini masuk dalam kategori central feasible karena petani akan lebih tertarik untuk menerapkannya apabila ada kebijakan pemberian subsidi yang berlaku, mengingat harga pupuk urea tablet yang relatif lebih mahal. Urea dalam bentuk tablet mempunyai sifat yang lebih basa ( $\mathrm{pH}$ 8) dibanding urea dalam bentuk prill karena ber-coating, selain itu penambahan urea dalam bentuk tablet menyebabkan reaksi oksidasi dalam tanah 
Arianti, M., Setyanto, P., Ardiansyah, M. (2016). Biaya Pengurangan (Marginal Abatement Cost) Emisi Gas Rumah Kaca(GRK) Sektor PErtanian di Kabupaten Grobogan dan Tanjung Jabung Timur. Jurnal Ilmu Lingkungan. 14(1),39-49, doi:10.14710/jil.14.1.39-49

menjadi lebih besar dibanding reaksi reduksi terkait dengan ketersediaan kation dan anion, sehingga nilai potensial redoks manjadi positif. Hal ini terutama berpengaruh pada proses pembentukan gas $\mathrm{CH}_{4}$, dimana gas ini optimal terbentuk pada kondisi keasaman tanah 6-7 dan potensial redoks -150 sampai - $200 \mathrm{mV}$.

Teknologi tanpa olah tanah dan tanam benih langsung termasuk high feasible, terutama di Kabupaten Tanjung Jabung Timur dimana sebagian besar areal sawah adalah di lahan pasang surut. Teknologi ini meskipun tidak signifikan menaikkan produksi padi, akan tetapi sangat sesuai diterapkan di daetah pasang surut terutama berkaitan dengan pengelolaan tanah. Tanpa olah tanah berarti meminimalkan gangguan pada kandungan hara dalam tanah, sehingga mengurangi lepasnya karbon tersimpan dalam tanah karena adanya penurunan oksidasi, ddi daerah pasang surut, hal ini berarti menghindari lepasnya pirit yang terbentuk di dalam tanah pada saat tergenang air laut atau sungai. Sementara teknologi tanam benih langsung termasuk low feasible, karena pada umumnya, teknologi ini banyak diterapkan oleh petani di daerah atau pada saat minimnya air.

Teknologi ameliorasi, termasuk dalam kategori yang high feasible, hal ini karena penerapan teknologi ameliorasi ini selain mampu menurunkan emisi GRK, juga sebagai bahan pembenah unsur hara tanah sehingga hasil padi menjadi meningkat, dalam hal ini dimungkinkan bagi pemerintah untuk mengeluarkan peraturan mengenai penerapannya oleh petani. Sebesar 63.922 $\mathrm{tCO}_{2} \mathrm{e} /$ th emisi GRK di Kabupaten Tanjung Jabung Timur dapat diturunkan pada tingkat adopsi teknologi yang tinggi.

Amelioran adalah bahan yang dapat meningkatkan kesuburan tanah melalui perbaikan kondisi fisik dan kimia. Kriteria amelioran yang baik bagi lahan gambutadalah memiliki kejenuhan basa (KB) yang tinggi, mampu meningkatkan derajat $\mathrm{pH}$ secara nyata, mampu memperbaiki struktur tanah, memiliki kandungan unsur hara yang lengkap, dan mampu mengusir senyawa beracun terutama asam-asam organik. Amelioran dapat berupa bahan organik maupun anorganik, Pemberian bahan amelioran seperti pupuk organik, tanah mineral, zeolit, dolomit, fosfat alam, pupuk kandang, kapur pertanian, abu sekam, purun tikus (Eleocharis dulcis) dapat meningkatkan pH tanah dan basa-basa tanah (Subiksa et al, 1997; Salampak, 1999; Mario, 2002). Penambahan bahan-bahan amelioran yang banyak mengandungkation polivalen juga dapat mengurangi pengaruh buruk asam-asam organik beracun. Lahan sawah di Kabupaten Tanjung Timur sebagian besar (lebih dari 70\%) berada pada daerah pasang surut dengan jenis tanah gambut sehingga pemberian bahan ameliorant, selain akan memperbaiki struktur tanah gambut yang miskin hara, juga dapat menurunkan emisi GRK (Balingtan, 2008,2009,2010,2011).

Kurva biaya pengurangan emisi GRK di Kabupaten Grobogan menunjukkan bahwa sebesar $212.822 \mathrm{tCO}_{2} \mathrm{e} /$ th atau sekitar $24 \%$ sampai dengan tahun 2020 dapat diturunkan dengan biaya dibawah Rp 1.000,-/ $\mathrm{tCO}_{2} \mathrm{e}$ dan tambahan penurunan emisi sebesar 5.532 $\mathrm{tCO}_{2} \mathrm{e} /$ th atau $0,12 \%$ bisa dicapai dengan biaya tambahan sebesar Rp, 3.582,-/ $\mathrm{tCO}_{2} \mathrm{e}$, sedangkan di Kabupaten Tanjung Jabung Timur, sebesar $66.317 \mathrm{tCO}_{2} \mathrm{e} /$ th atau sekitar 8,1\% sampai tahun 2020 dapat diturunkan dengan biaya tambahan dibawah $\mathrm{Rp} 1.000,-/ \mathrm{tCO}_{2} \mathrm{e}$. Penurunan sebesar $24 \%$ di Kabupaten Grobogan tersebut akan diperoleh dengan penerapan teknologi mitigasi berupa penggunaan varietas padi yang rendah emisi, sistem pengairan berselang dan cara tanam dengan tabela (tanam benih langsung) pada luasan padi sawah tertentu.

Pemilihan aksi mitigasi yang paling menguntungkan secara ekonomi maupun lingkungan dapat dilakukan dengan melihat pada kurva biaya pengurangan emisi GRK. Kabupaten Grobogan akan mendapatkan keuntungan lingkungan dan ekonomi yang maksimal dengan menerapkan aksi mitigasi PTT dan penggantian varietas dengan varietas padi yang rendah emisi, yaitu hanya dengan tambahan biaya pengurangan Rp 100-150,$/ \mathrm{tCO}_{2} \mathrm{e}$ dapat menurunkan emisi sebesar $181.312 \mathrm{tCO}_{2} \mathrm{e} /$ th. Sementara Kabupaten Tanjung Jabung Timur dengan penerapan aksi mitigasi penambahan bahan amelioran mampu menurunkan emisi sebesar $19.304 \mathrm{tCO}_{2} \mathrm{e} / \mathrm{th}$ dengan tambahan biaya sebesar Rp 150-450,$/ \mathrm{tCO}_{2} \mathrm{e}$. Biaya-biaya tersebut dihitung hanya berdasarkan biaya pada faktor input usahatani seperti tenaga kerja dan penggunaan pupuk, sementara biaya penggunaan bahan bakar selama proses usahatani tidak diperhitungkan, seperti halnya biaya-biaya sosial. Biaya-biaya ini dimungkinkan berubah seiring dengan perubahan kebijakan oleh pemerintah.

Potensi pengurangan emisi dengan kemungkinan adopsi teknologi seperti tertera dalam Tabel 6. Dalam hal ini terdapat 3 macam kemungkinan adopsi untuk masing-masing teknologi, yaitu:high feasible, central feasible dan low feasible. Menurut Moran et al, (2010) dan MacLeod et al, (2010), high feasible adalah kemungkinan tingkat adopsi petani terhadap suatu teknologi mitigasi apabila ada peraturan pemerintah, sementara central feasible adalah apabila selain terdapat peraturan pemerintah untuk menerapkan suatu teknologi, juga 
diberlakukan pemberian subsidi bagi yang menerapkannya, dan low feasible adalah kemungkinan adopsi teknologi jika pemerintah mensosialisasikannya melalui pendidikan/informasi saja jika sesuai untuk suatu kondisi tertentu. Di Kabupaten Grobogan, sebesar $181.310 \quad \mathrm{tCO}_{2} \mathrm{e} / \mathrm{th}$ dapat dikurangi dengan kemungkinan adopsi yang tinggi (high feasible) yaitu melalui penerapan program PTT (Pengelolaan Tanaman Terpadu) dan penggunaan varietas rendah emisi. Penerapan PTT merupakan kebijakan yang telah diterapkan pemerintah melalui keputusan menteri pertanian, dan penggunaan varietas rendah emisi dimungkinkan untuk diterapkan dengan adanya peraturan yang sejenis.

Besaran penurunan emisi berdasarkan asumsi bahwa luas lahan sawah meningkat secara linear, sementara biaya dihitung berdasarkan tingkat diskon 8\%/th. Akan tetapi hal ini tentu saja masih sangat tergantung pada kebijakan pemerintah yang diberlakukan. Tingkat adopsi oleh petani, selain dipengaruhi oleh kebijakan pemerintah, juga akan dipengaruhi oleh pola hidup, seperti diketahui bahwa sebagian besar petani tidak menerima keuntungan finansial yang maksimum, sehingga pola hidup mereka dipengaruhi oleh banyak faktor termasuk kondisi pasar (misal: harga sarana produksi pertanian dan juga harga jual hasil pertanian). Pike (2008) dalam Bates, 2001 mengemukakan bahwa kondisi pasar merupakan satu set faktor yang mempengaruhi pengambilan keputusan dalam usahatani, yaitu termasuk faktor internal (pengetahuan, kebiasaan dan prilaku), faktor sosial (norma dan peraturan), kebijakan terkait lingkungan dan faktor-faktor lainnya.

\section{KESIMPULAN}

Penentuan teknologi mitigasi dapat dilakukan melalui studi literatur, sementara penentuan luasan area yang berpotensi untuk penerapan teknologi mitigasi, dilakukan dengan membangun asumsi-asumsi. Besaran biaya dapat ditentukan berdasarkan pada biaya yang berlaku setempat.Kurva biaya pengurangan emisi GRK di Kabupaten Grobogan menunjukkan bahwa sebesar $212.822 \mathrm{tCO}_{2} \mathrm{e} /$ th atau sekitar $24 \%$ sampai dengan tahun 2020 dapat diturunkan dengan biaya dibawah $\mathrm{Rp} 1.000,-/ \mathrm{tCO}_{2} \mathrm{e}$, sementara di Kabupaten Tanjung Jabung Timur, sebesar $66.317 \mathrm{tCO}_{2} \mathrm{e} /$ th atau sekitar $8,1 \%$ sampai tahun 2020 dapat diturunkan dengan biaya tambahan dibawah Rp 1.000,-/ $/ \mathrm{tCO}_{2} \mathrm{e}$.

Teknologi mitigasi yang berpotensi besar menurunkan emisi GRK dengan biaya rendah di Kabupaten Grobogan adalah penerapan teknik budidaya PTT dan penggantian varietas padi dengan varietas padi yang teridentifikasi rendah emisi GRK. Sementara di Kabupaten Tanjung Jabung Timur, teknologi ameliorasi dengan kompos, pupuk kandang maupun daun babadotan merupakan teknologi mitigasi yang memiliki potensi besar menurunkan emisi dengan biaya yang rendah.

Tingkat adopsi teknologi mitigasi oleh petani, akan sangat dipengaruhi oleh kebijakan yang dikeluarkan oleh pemerintah setempat. Oleh karena itu, introduksi sebuah teknologi mitigasi hendaknya juga memberikan keuntungan ekonomi pada pengguna. Ke depan, perhitungan biaya tambahan untuk penurunan emisi (MAC) yang lebih detail dengan memasukkan komponen biaya social, pajak serta biaya bahan bakar dalam usahatani hendaknya dilakukan untuk memberikan gambaran yang lebih nyata terhadap abatement cost.

\section{DAFTAR PUSTAKA}

[ADB]Asian Development Bank. 1998. Asia Least-cost Greenhouse Gas Abatement Strategy. Philippines. Asian Development Bank Publisher.

Aulakh, M.S., R.Wassmann, C.Bueno, H. Rennenberg. 2001. Impact of root exudates of different cultivars and plant development stages of rice (Oryza sativa L.) on methane production in a paddy soil. Plant Soil, 230pp. 77-86. Doi: 10.1023/A:1004817212321

Aulakh, M.S., R.Wassmann, H. Rennenberg. 2002. Methane transport capacity of twenty-two rice cultivars from five major Asian rice-growing countries.Journal ofAgricultural, Ecosystem \& Environment, 91pp. 5971. PII: S 0167/8809(01)00260-2

Bates, J. 2001. Economics evaluation of emission reductions of nitrous oxides and methane in agriculture in the EU: bottom up analysis. In : Contribution to a study for DG Environment. European Commission by Ecofys Energy and Environmnent and National Technical University of Athens.

Beach, R.H., B.J. DeAngelo, S. Rose ,C. Li, W. Salas, S.J. DelGrosso. 2008. Mitigation potential and cost for global agricultural greenhouse gas emission.Journal of Agricultural Economics 38 (2), pp . 109-115. Doi: 10.1111/j.1574-0862.2008.00286.x

[BPS] Badan Pusat Statistik. 2010. Propinsi Jambi Dalam Angka. Jambi (ID) :BPS

[BPS] Badan Pusat Statistik. 2011. Propinsi Jawa Tengah Dalam Angka. Jawa Tengah (ID): BPS

[BPS] Badan Pusat Statistik. 2011. Grobogan Dalam Angka. Grobogan (ID) : BPS

[BPS] Badan Pusat Statistik. 2011. Tanjung Jabung Timur Dalam Angka. Tanjung Jabung Timur (ID) : BPS

Cao, M., J.B. Dent, O.W. Heal. 1995. Methane emissions from China's paddyland. Journal of Agriculture, Ecosystems and Environment 55 (2): 129-137. SSDI 0167-8809 (95) 00613-3

DeAngelo, B.J., F.C. de la Chesnaye, R.H. Beach, A. Sommer, B.C. Murray. 2006. Methane and nitrous oxide mitigation in agriculture. The Energy Journal, Special Issue, pp 89-108.

DeCara, S., M. Houze, P.A Jayet. 2011. Marginal abatement cost of greenhouse gas emission from European agriculture, cost effectiveness, and the EU non-ETS burden sharing agreement. Ecological Economics70 : 1680-1690. Doi: 10.1016/j.ecolecon.2011.05.007 
Arianti, M., Setyanto, P., Ardiansyah, M. (2016). Biaya Pengurangan (Marginal Abatement Cost) Emisi Gas Rumah Kaca(GRK) Sektor PErtanian di Kabupaten Grobogan dan Tanjung Jabung Timur. Jurnal Ilmu Lingkungan. 14(1),39-49, doi:10.14710/jil.14.1.39-49

[IEA] International Energy Agency. 2009. Methodology for Calculating Electricity and Heat Marginal Abatement Cost Curves (MACC). World Energy Outlook. International Energy Agency, Paris.

[Second Natcom] Indonesia SecondNational Communication Under The United NationsFramework Convention on Climate Change (UNFCCC). 2010. Presentand Future Generation. Kementrian Lingkungan Hidup.

[IPCC] Inter-governmental Panel on Climate Change. 2006. IPCC Guidelines for National Greenhouse Gas Inventories. Prepared by The National Greenhouse Gas Inventories Programme, Eggleton HS, Buendia L, Miwa K, Ngara T. and Tanabe K. (eds.). Penerbit IGES Jepang.

Las I. 2007. Antisipasi Perubahan Iklim dalam Tabloid Sinar Tani edisi 14 - 20 November 2007.

Laporan Tahunan Balingtan 2004. Balai Penelitian Lingkungan Pertanian. Pati (ID): Balingtan. Jawa Tengah

Laporan Tahunan Balingtan 2005. Balai Penelitian Lingkungan Pertanian. Pati (ID): Balingtan. Jawa Tengah

Laporan Tahunan Balingtan 2008. Balai Penelitian Lingkungan Pertanian. Pati (ID): Balingtan. Jawa Tengah

Laporan Tahunan Balingtan 2009. Balai Penelitian Lingkungan Pertanian. Pati (ID): Balingtan. Jawa Tengah

Laporan Tahunan Balingtan 2010. Balai Penelitian Lingkungan Pertanian. Pati (ID): Balingtan. Jawa Tengah

Laporan Tahunan Balingtan 2011. Balai Penelitian Lingkungan Pertanian. Pati (ID): Balingtan. Jawa Tengah

Levy, P.E., D.C. Mobbs, S.K. Jones, R. Milne,C. Campbell, M.A.Sutton. 2007. Simulation of Fluxes of Greenhouse Gases from European Grasslands Using the DNDC Model. Journal ofAgriculture, Ecosystems and Environment 121 : 186 - 192. Doi : 10.1016/j.agee.2006.12.019.

Mario, M.D. 2002. Peningkatan Produktivitas dan Stabilitas Tanah Gambut dengan Pemberian Tanah Mineral yang Diperkaya oleh Bahan Berkadar Besi Tinggi[Disertasi]. Bogor (ID) :Program Pascasarjana, Institut Pertanian Bogor.

MacLeod, M., D. Moran,E. Wall, V. Eory, A. McVittie, A. Barnes, R. Rees, C. Topp, G. Pajot, R. Matthews, P. Smith, A. Moxey. 2010. Developing greenhouse gas marginal abatement cost curve for agricultural emission from crops and soil in the UK. Journal of Agricultural System 103 : 198-209. Doi:10.1016/j.agsy.2010.01.002.

McKinsey \& Company, 2008. Pathways to a low-carbon economy - global greenhouse gases (GHG) abatement costs curve. Version 1 of The Global Greenhouse Gas Abatement Costs Curve.

McKinsey \& Company, 2009. Pathways to a low-carbon economy - global greenhouse gases (GHG) abatement costs curve. Version 2 of The Global Greenhouse Gas Abatement Costs Curve (http://globalghgcostcurve.bymckinsey.com/) akses 4 september 2013

Moran, D., M.MacLeod, E. Wall, V. Eory, A. McVittie, A. Barnes, R. Rees, C. Topp, G. Pajot, R. Matthews,
P.Smith, A. Moxey. 2010. Marginal abatement costs curves for UK agricultural greenhouse gas emissions. Journal of Agricultural Economics. Doi: 10.1111/j.1477-9552.2010.00268.x.

2011. Developing carbon budgets for UK agriculture, land use, land-use change and forestry out to 2022.Climate Change 105 (34) : 43-49. Doi :10.1007/s10584-0109898-2

[Perpres 61]Peraturan Presiden. 2011.Rencana Aksi Nasional Penurunan Emisi Gas Rumah Kaca (GRK)Nasional. Pemerintah Indonesia.

[Perpres 71] Peraturan Presiden. 2011. Penyelenggaraan Inventarisasi GRK oleh Pemerintah Pusat, Provinsi dan $\mathrm{Kab} /$ Kota. Pemerintah Indonesia

Sathaye, A. Jayant, S.Meyers. 1995.Greenhouse Gas Mitigation: A Guideline. [http://ies.lbl.gov/iespubs/ggma/ghgcontents.html]

Setyanto,P., A.K. Makarim, A.M. Fagi, R. Wassmann, L.V. Buendia. 2000. Crop management affecting methane emission from irrigated and rainfed rice in central Java. Journal of Nutrient Cycling Ecosystem.58 : 85-93

Setyanto, P., A.B. Rosenani, C.I. Fauziah. 2002. Influence of soil properties on $\mathrm{CH}_{4}$ emission from rice field. Indonesian Journal of AgriculturalScience. IAARRD. MoA Indonesia

Setyanto, P., A.B. Rosenani, R. Boer, C.I.Fauziah, M.J.Khanif . 2005. The Effect of Rice Cultivars on Methane Emission From Irrigated Rice Field.Indonesian Journal of Agricultural Science. IAARRD. MoA Indonesia

Setyanto, P., M.Ariani, A.K.Makarim. 2010. Reduksi emisi metana melalui varietas padi.Prosiding Seminar dan Lokakarya Nasional Inovasi Sumberdaya Lahan Pertanian. 2010. Buku I. BBSDLP hal. 231-245. ISBN 978-979-8039-24-6

Setyanto, P. and R. Kartikawati. 2011. Integrated rice crop management for low emitance of methane.Indonesian Journal of Agriculture Sciences 4 (1): 8-16.

Subiksa, I.G.M., K.Nugroho, M. Sholeh, I.P.G.Widjaja Adhi 1997. The effect of ameliorants on the chemical properties and productivity of peat soil. In: Rieley and Page (Eds). pp:321-326. Biodiversity and Sustainability of Tropical Peatlands.Samara Publishing Limited, UK

[USEPA] Unied Nation Environmental Protection Agency. 2005. Greenhouse gas mitigation potential in US forestry and agriculture. EPA 430-R-05-006. Washington, DC : US Environmental Protection Agency.

Vermont, B. and S. DeCara. 2010. How costly is mitigation of non- $\mathrm{CO}_{2}$ greenhouse gas emission from agriculture? A meta analyisis. Ecological Economics 69 (7) :13731386.doi:10.1016/j.ecolecon.2010.02.020

Weiske, A. 2005. Survey of technical and managementbased mitigation measures in agriculture.Impact of environmental agreements on the common agricultural policy, Institute

Weiske, A. 2006. Selection and specification of technical and management-based measures in agricultural production for modelling.Impact of environmental agreements on the common agricultural policy, Institute of European environmental policy. London. 